\title{
Influence of Irradiance and Period of Exposure on Fruit Set of French-American Hybrid Grapes
}

\author{
D.C. Ferree, S.J. McArtney, and D.M. Scurlock \\ Department of Horticulture and Crop Science, The Ohio State University/OARDC, 1680 Madison \\ Avenue, Wooster, OH 44691-4096
}

\begin{abstract}
AdDitional INDEX wORDs. Vitis vinifera L., chlorophyll, photosynthesis, cluster weight, shot berries
Abstract. Vines of container grown 'DeChaunac', 'Vidal blanc', 'Seyval blanc' and 'Chambourcin' grapes were subjected to 5 days of $80 \%$ shade at prebloom, bloom or 2 and 4 weeks after bloom. Fruit set, cluster weight, berries per cluster and juice components [soluble solids concentration (SSC), pH and titratable acidity] of 'DeChaunac' and 'Vidal blanc' were not affected by a short period of intensive shade. 'Chambourcin' was sensitive to a shade period near the time of bloom for most of the aforementioned factors, while 'Seyval blanc' was intermediate in sensitivity. Shot (green, hard, and undersized) berries of 'Chambourcin' and 'Seyval blanc' were increased by a 5-day period of shade 2 or 4 weeks after bloom. In a second study, container-grown 'Chambourcin' on 3309C ( $V$. riparia $x$ V. rupestris) with one or two clusters and 'Vidal blanc' with one cluster were subjected to the following light regimes beginning at bloom for 5 weeks: supplemental light, ambient greenhouse light and $30 \%, 50 \%$ or $80 \%$ shade. Yield, fruit set, specific leaf weight (leaf dry weight/leaf area), saturation index, and total leaf chlorophyll increased linearly with increasing irradiance. 'Chambourcin' juice $\mathbf{~ H H}$, SSC, leaf chlorophyll a/b ratio, cluster color development and hue angle decreased as irradiance increased, likely related to crop reduction. Responses in 'Vidal blanc' followed similar trends, but differences were not as great. Results demonstrate that light is an important determining factor in fruit set of French-American hybrid grapes and fruit set of some cultivars are sensitive to short periods of intense shade.
\end{abstract}

Fruit set of two French-American hybrid grape cultivars [Vitis vinifera L. $\mathrm{x}$ Vitis L. (complex interspecific hybrids)] was reduced by exposure to low light conditions from shortly after bloom through harvest (Hummell and Ferree, 1997). Earlier work with Vitis vinifera L. cultivars in the field (Nuno, 1993; Ollat, 1993) or in controlled environment (Roubelakis and Kliewer, 1976) showed reduced fruit set with heavy shading. Data from other studies (Ebadi et al., 1995, 1996) indicated that low temperature before or at bloom had a greater effect on fruit set of $V$. vinifera cultivars than light, although light tended to have a role. The irradiance and the time when fruit set of grape was most sensitive was not well defined by these studies.

A number of studies with apple [Malus syslvestris (L.) Mill var. domestica (Borkh) Mansf.] have shown that areas of the canopy with the highest light levels have the highest fruit set, largest fruit size, and highest soluble solids concentration (SSC) (Doud and Ferree, 1980; Ferree, 1980; Warrington et al., 1996). Fruit set can be reduced by as little as 3 to $5 \mathrm{~d}$ of heavy shade when it is applied during the critical 14 to $28 \mathrm{~d}$ period after bloom (Byers and Carbaugh, 1991; Byers et al., 1991; Polomski et al., 1988).

Since many viticulture areas can experience short periods near the time of bloom of heavy cloud cover (shade) or years with extended periods of reduced light due to rain or cloudy conditions, the following study was conducted to determine sensitivity of fruit set of grape to shade and the effect of selected irradiances on grape berry growth and development. The hypothesis tested was that light is a determining factor for fruit set of grape and cultivars differ in their sensitivity to light and its effect on fruit set. In the first study, four French-American hybrid grape cultivars were shaded for a 5-d period at four times near the time of bloom to determine when fruit set was most sensitive to shade. The second study evaluated the influence of five irradiances estab-

Received for publication 10 Apr 2000. Accepted for publication. Manuscript no HCS00-14. Salaries and research support provided by State and Federal Funds appropriated to the Ohio Agricultural Research and Development Center, The Ohio State University. The cost of publishing this paper was defrayed in part by the payment of page charges. Under postal regulations, this paper therefore must be hereby marked advertisement solely to indicate this fact. lished at bloom and continuing for 5 weeks on fruit set and berry development of two grape cultivars.

\section{Materials and Methods}

EFFects of Timing OF SHADE. 'DeChaunac', 'Seyval blanc', 'Vidal blanc' (hereafter referred to as 'Seyval' and 'Vidal') and 'Chambourcin' grapevines propagated on their own roots during late Winter 1996, were potted in 8-L nursery containers with a medium of 1 soil : 1 peat : 1 perlite (by volume). Vines were grown outdoors during Summer 1996 and trained to a single shoot. In November, vines were moved to a dark storage at $5 \pm 3^{\circ} \mathrm{C}$ and held until they were moved to a greenhouse in Feb. 1997. Each pot received $15 \mathrm{~g}$ of a slow release fertilizer (Osmocote 14-7-13, Scotts-Sierra Hort Products, Marysville, Ohio). Vines were then pruned to three nodes, and as soon as a shoot with a single cluster was identified, it was retained and the others removed. Vines were trained as a single shoot attached to a bamboo pole in each pot. At the start of the study, vines were grouped by shoot length (longest in first replication) and randomly assigned treatments. Vines with a single flower cluster were placed under $80 \%$ shade cloth for 5 $\mathrm{d}$ at the following time periods beginning 13 Mar.: prebloom, bloom ('DeChaunac' 18 Mar., other cultivars 20 Mar.), bloom plus 2 weeks, bloom plus 4 weeks, and nonshaded controls. The experimental design was a randomized complete block with a factorial arrangement of treatments (four cultivars $\times$ five times) with five individual vine replications, for a total of 100 vines.

The number of flowers on each cluster was counted in March just before the prebloom treatment. At harvest, cluster weight and number berries and shot (green, hard, and undersized) berries was counted to determine fruit set (berries per 100 flowers). All treatments of a cultivar were harvested on the same day. Berry color was recorded on five berries selected at random in the midsection of the main cluster with a chromometer (model CR100; Minolta, Ramsey, N.J.). All readings were recorded in the L* $a^{*} b^{*}$ mode and converted to Hunter Lab values of $L(100=$ bright, $0=$ dark $)$, (positive $=$ red, negative $=$ green $)$, and $\mathrm{b}($ positive $=$ yellow, negative $=$ blue). The values were converted to hue angle 
and saturation index (SI) using the following equations: hue angle $=\left(\tan ^{-1} \mathrm{~b} / \mathrm{a}\right)$ and $\mathrm{SI}=\left(\mathrm{a}^{2}+\mathrm{b}^{2}\right) \mathrm{a} / 2$.

The berries were crushed and soluble solids concentration (SSC), $\mathrm{pH}$, and titratable acidity (TA) recorded from fresh samples. SSC were measured with a refractometer (model $10480 \mathrm{~S} / \mathrm{N}$; Abbe AO Scientific Instruments, Kenne, N.Y.). A calibrated digital ionalyzer (model 701a; Orion Research, Cambridge, Mass.) was used to determine $\mathrm{pH}$. TA was determined by diluting $5 \mathrm{~mL}$ of juice in $100 \mathrm{~mL}$ of double-distilled water and titrating with $\mathrm{NaOH}$ to $\mathrm{pH} 8.2$.

EFFECTS OF IRRADIANCE. Vines of 'Chambourcin' on 3309C rootstocks were potted in 16-L nursery containers with a medium of 1 soil : 1 peat : 1 perlite (by volume). The vines were handled as described previously. Vines were cluster thinned to one or two flower clusters per vine. At bloom they were placed in one of the following light environments for 5 weeks: 1) ambient, 2) ambient plus supplemental light from a $1000-\mathrm{W}$, high pressure sodium light operated from 0600 to $1900 \mathrm{HR}, 3) 30 \%$, 4) $50 \%$ or 5) $80 \%$ shade. Shade was provided by shade cloth placed over the vines and extended to the soil surface. Light and temperature in each of these environments were monitored with a quantum sensor (model 190; LI-COR, Lincoln, Nebr.) and thermocouple $1 \mathrm{~m}$ above the soil surface at cluster height attached to a data logger (model 21X; Campbell Scientific, Logan, Utah) that measured every minute with the output averaged over $15 \mathrm{~min}$. The light environments were repeated on each side of the greenhouse providing two replications of a factorial arrangement (two cluster levels $\times$ five light environments) with three vines of each treatment in each replication for a total of 60 vines. The correct polynominal orthagonal contrasts for unequally spaced treatments were calculated for the light levels using 20, 50, 70, 100, and 120 as the treatment values. Those calculated values were used as the coefficient for the contrasts. Shoot extension was measured weekly until vines had 15 leaves at which time they were topped. Laterals were removed weekly throughout the season.

Flower numbers per cluster were counted on the shoulder of the cluster and entire cluster just before bloom and cluster weight was recorded and the number of berries and shot berries was counted at harvest. Peduncle diameter was measured at bloom and again at harvest. Berry color and juice composition were determined as described previously. The terminal leaf that just opened was tagged when vines were placed in each light environment and one that was fully expanded and opposite the lower cluster before imposing the light treatments, were used for measurement of net photosynthesis $\left(\mathrm{P}_{\mathrm{n}}\right)$ and transpiration $(\mathrm{E})$ on 29 Apr. 1997. An infrared gas analyzer (model ADC LCA 2; Analytical Development Corp., Hoddesdon, United Kingdom) was used with a $6.25 \mathrm{~cm}^{2}$ Parkinson leaf chamber (Hoddesdon, United Kingdom). Air flow was regulated at $300 \mathrm{~mL} \cdot \mathrm{min}^{-1}$, with the air port outside the greenhouse. Ambient $\mathrm{CO}_{2}$ concentration, humidity of the air entering and leaving the leaf chamber, the chamber temperature and incident level of photosynthetically active radiation $(P A R)$ were recorded with each measurement. A measurement was taken at the ambient irradiance in the treatment and the vine was subsequently removed. A second measurement was taken on the same leaves at saturating irradiance. Following the 5 weeks exposure to the light treatments, chlorophyll was extracted from three leaf discs $\left(2.4 \mathrm{~cm}^{2}\right.$ total area) taken from the same two leaves on each shoot used to measure $P_{n}$ and $E$. Chlorophyll was measured using the N,N-dimethylformamide method according to Moran (1982).

At veraison (22 May 1997) the percentage of each fruit cluster showing color was recorded weekly. After harvest the vines were grown in the greenhouse for $30 \mathrm{~d}$ and then placed in dark storage at $5 \pm 3{ }^{\circ} \mathrm{C}$ for 5 months and returned to the greenhouse and cut back to four buds. When the shoots were $\approx 30 \mathrm{~cm}$, flower clusters per shoot were counted and cluster quality rated as $1=$ sparse cluster with few flowers to $4=$ dense cluster with many flowers.

'Vidal' plants in 8-L containers were handled as described previously. The same irradiance treatments were imposed, however, each vine had only one flower cluster. Similar data were collected. The irradiance treatments were replicated on two sides of the greenhouse with three plants of each treatment in each replication for a total of 30 plants.

\section{Results}

EFFEcts OF TIMING OF SHADE. 'Vidal' vines had fewer flowers per cluster at bloom than the other three cultivars, which did not differ in flowers per cluster (Table 1). At the time the treatments were imposed, 'Chambourcin' had the longest shoots followed by 'DeChaunac', 'Seyval', and 'Vidal'. 'Seyval' and 'Vidal' had fewer leaves than the other cultivars. Although leaf area was not measured, leaves of 'Chambourcin' were the largest, followed by 'Seyval', with 'Vidal' and 'DeChaunac' having smaller leaves. There was no interaction between cultivar and time of shading treatment for the vine characteristics at the time the treatments were applied. Vines in the bloom treatment had slightly more flowers per cluster and prebloom vines slightly fewer leaves than the other treatments.

Fruit set of 'DeChaunac' and 'Vidal' were not influenced by $5 \mathrm{~d}$ of $80 \%$ shade, while set of 'Seyval' was reduced by shade that occurred at bloom and 1 week before or 2 weeks after bloom (Table 2). Fruit set of 'Chambourcin' was increased by exposure to shade prior to bloom, while shade at bloom decreased set. Cluster weight at harvest was reduced on 'Chambourcin' by exposure to shade at bloom and 2 and 4 weeks following bloom, while cluster weight of the other cultivars was not influenced by exposure to short periods of shade. At harvest, partitioning the

Table 1. Number of flowers per cluster, shoot length, and number of leaves on four French-American hybrid grapevines at time of bloom.

\begin{tabular}{lccc}
\hline \hline & $\begin{array}{c}\text { Flowers/ } \\
\text { cluster }\end{array}$ & $\begin{array}{c}\text { Shoot } \\
\text { length } \\
(\mathrm{cm})\end{array}$ & $\begin{array}{c}\text { Leaves } \\
\text { (no.) }\end{array}$ \\
Parameter & $472 \mathrm{a}^{\mathrm{z}}$ & $125 \mathrm{~b}$ & $14.7 \mathrm{a}$ \\
\hline Cultivar $(\mathrm{C})$ & $515 \mathrm{a}$ & $96 \mathrm{c}$ & $12.4 \mathrm{~b}$ \\
$\quad$ DeChaunac & $255 \mathrm{~b}$ & $71 \mathrm{~d}$ & $11.4 \mathrm{~b}$ \\
Seyval & $470 \mathrm{a}$ & $157 \mathrm{a}$ & $15.0 \mathrm{a}$ \\
$\quad$ Vidal & & & \\
$\quad$ Chambourcin & $394 \mathrm{~b}$ & 120 & $13.6 \mathrm{a}$ \\
Time of shading (T) & $396 \mathrm{~b}$ & 99 & $12.1 \mathrm{~b}$ \\
Control & $528 \mathrm{a}$ & 107 & $14.2 \mathrm{a}$ \\
Prebloom & $370 \mathrm{~b}$ & 118 & $13.3 \mathrm{a}$ \\
Bloom & $447 \mathrm{ab}$ & 120 & $13.7 \mathrm{a}$ \\
Bloom +2 weeks & & & $* *$ \\
Bloom +4 weeks & $*$ & $* *$ & $* *$ \\
Significance & $* *$ & NS & NS \\
C & NS & NS & \\
T & &
\end{tabular}

$\overline{{ }^{\mathrm{z}} \text { Mean separation in columns for main effects of cultivar and time of }}$ shading by Duncan's multiple range, $P<0.05$.

ns,*,**N Nonsignificant or significant at $P<0.05$ or 0.01 , respectively. 
Table 2. Influence of $5 \mathrm{~d}$ of shade at different times near the time of bloom on fruit set, cluster weight, berries and shot berries per cluster of four French-American hybrid grape cultivars.

\begin{tabular}{|c|c|c|c|c|c|c|c|c|c|c|}
\hline \multirow[b]{2}{*}{ Cultivar } & \multicolumn{10}{|c|}{ Time of $5 \mathrm{~d}$ of $80 \%$ shade } \\
\hline & Control & Prebloom & Bloom & $\begin{array}{l}\text { Bloom + } \\
2 \text { weeks }\end{array}$ & $\begin{array}{c}\text { Bloom + } \\
4 \text { weeks }\end{array}$ & Control & Prebloom & Bloom & $\begin{array}{l}\text { Bloom + } \\
2 \text { weeks }\end{array}$ & $\begin{array}{r}\text { Bloom + } \\
4 \text { weeks }\end{array}$ \\
\hline & \multicolumn{5}{|c|}{ Fruit set $(\%) ; \mathrm{LSD}_{0.05}=16.0$} & \multicolumn{5}{|c|}{ Berries/cluster; LSD $_{0.05}=58$} \\
\hline DeChaunac & 28.2 & 26.5 & 20.4 & 23.4 & 30.3 & $\overline{108}$ & 111 & 89 & 82 & 119 \\
\hline Seyval & 53.6 & 29.6 & 28.4 & 34.4 & 47.1 & 175 & 112 & 167 & 108 & 201 \\
\hline Vidal & 48.1 & 49.3 & 34.3 & 49.7 & 48.7 & 114 & 122 & 99 & 83 & 126 \\
\hline \multirow[t]{2}{*}{ Chambourcin } & 47.3 & 68.6 & 29.2 & 50.0 & 44.3 & 212 & 252 & 151 & 131 & 160 \\
\hline & \multicolumn{5}{|c|}{ Cluster wt $(\mathrm{g}) ; \mathrm{LSD}_{0.05}=119$} & \multicolumn{5}{|c|}{ Shot berries/cluster; $\mathrm{LSD}_{0.05}=22.6$} \\
\hline Dechaunac & 188 & 210 & 171 & 163 & 186 & 8.0 & 2.4 & 2.0 & 15.0 & 7.4 \\
\hline Seyval & 275 & 174 & 263 & 198 & 342 & 17.4 & 7.5 & 9.3 & 46.3 & 85.7 \\
\hline Vidal & 182 & 185 & 166 & 104 & 191 & 3.8 & 7.4 & 3.4 & 2.0 & 5.2 \\
\hline Chambourcin & 623 & 717 & 447 & 394 & 473 & 24.2 & 26.0 & 2.0 & 51.8 & 55.0 \\
\hline
\end{tabular}

clusters into berries or shot berries showed no influence on either with 'DeChaunac' or 'Vidal'. Berries per cluster of 'Seyval' were reduced by exposure to shade either prebloom or 2 weeks following bloom. Shot berries per cluster were increased on 'Seyval' and 'Chambourcin' by a shade period 2 or 4 weeks following bloom, while shot berries were not influenced by any shade period for 'DeChaunac' or 'Vidal'.

A significant interaction occurred between shade period and cultivar for juice SSC and $\mathrm{pH}$ (Table 3). A 5-d period of shade had no effect on SSC in juice of 'DeChaunac', 'Seyval', or 'Vidal' but with 'Chambourcin', shade prebloom reduced and at bloom or 2 weeks after bloom increased SSC. While juice $\mathrm{pH}$ of other cultivars was not affected by shade period, $\mathrm{pH}$ of 'Chambourcin' juice was increased by shade applied at bloom or 2 and 4 weeks after bloom. Measurement of the color variables of berries at harvest showed an increase in SI of 'Vidal' berries exposed to shade 2 weeks after bloom, while SI of other cultivars was not influenced by shade period.

EFFECTS OF IRRADIANCE. Temperature measurements at cluster level in the treated area indicated that temperature tended to be slightly higher in the supplemental light and $80 \%$ shade treat- ments (Fig. 1A). Temperatures in the $50 \%$ shade treatment tended to be slightly lower than ambient greenhouse temperatures. Daily accumulation of irradiances in the treated areas showed that fluctuations resulting from outside light conditions were minimized as the degree of shade increased (Fig. 1B). However, expected differences existed among the treatments and is shown clearly by the percentage ambient light (Fig. 1C) and cumulative light over the 5-week treatment period (Fig. 1D).

Vines with two clusters had higher cluster weight per vine and lower peduncle diameter between bloom and harvest relative to vines with one cluster (Table 4). Increasing irradiance increased yield, and cluster length and width. Peduncle diameter growth from bloom to harvest decreased as irradiance increased. Fruit set on both the shoulder and main cluster increased as irradiance increased, while the set of shot berries was unaffected. Shoulder and main cluster berries per plant were increased by retaining two clusters/plant and by increasing irradiance during the 5 weeks following bloom. The interaction between number of clusters and light level for berries resulted from relatively more berries on a vine with a single cluster and $30 \%$ shade, while just the opposite was true for $80 \%$ shade. One of the purposes of keeping separate

Table 3. Influence of $5 \mathrm{~d}$ of shade at different times near the time of bloom on juice SSC, pH, and SI measurement of color of four French-American hybrid grape cultivars.

\begin{tabular}{|c|c|c|c|c|c|}
\hline \multirow[b]{2}{*}{ Cultivar } & \multicolumn{5}{|c|}{ Time of $5 \mathrm{~d}$ of $80 \%$ shade } \\
\hline & Control & Prebloom & Bloom & $\begin{array}{l}\text { Bloom + } \\
2 \text { weeks }\end{array}$ & $\begin{array}{r}\text { Bloom + } \\
4 \text { weeks }\end{array}$ \\
\hline & \multicolumn{5}{|c|}{$\operatorname{SSC}(\%) ; \operatorname{LSD}_{0.05}=2.0$} \\
\hline DeChaunac & 20.3 & 19.9 & 20.4 & 20.9 & 20.2 \\
\hline Seyval & 20.8 & 21.0 & 20.5 & 21.6 & 19.8 \\
\hline Vidal & 16.9 & 17.8 & 16.9 & 17.0 & 18.8 \\
\hline Chambourcin & 21.1 & 18.2 & 23.3 & 24.0 & 22.7 \\
\hline \multicolumn{6}{|c|}{$\mathrm{pH} ; \mathrm{LSD}_{0.05}=0.10$} \\
\hline DeChaunac & 3.09 & 3.10 & 3.16 & 3.13 & 3.07 \\
\hline Seyval & 3.14 & 3.17 & 3.13 & 3.19 & 3.15 \\
\hline Vidal & 3.10 & 3.08 & 3.15 & 3.12 & 3.12 \\
\hline Chambourcin & 3.33 & 3.27 & 3.60 & 3.54 & 3.54 \\
\hline \multicolumn{6}{|c|}{$\mathrm{SI} ; \mathrm{LSD}_{0.05}=1.61$} \\
\hline DeChaunac & 0.21 & 0.37 & 0.26 & 0.46 & 0.68 \\
\hline Seyval & 8.33 & 7.61 & 7.42 & 6.67 & 8.54 \\
\hline Vidal & 6.65 & 7.25 & 7.44 & 11.12 & 7.00 \\
\hline Chambourcin & 0.43 & 0.71 & 0.35 & 0.49 & 0.39 \\
\hline
\end{tabular}



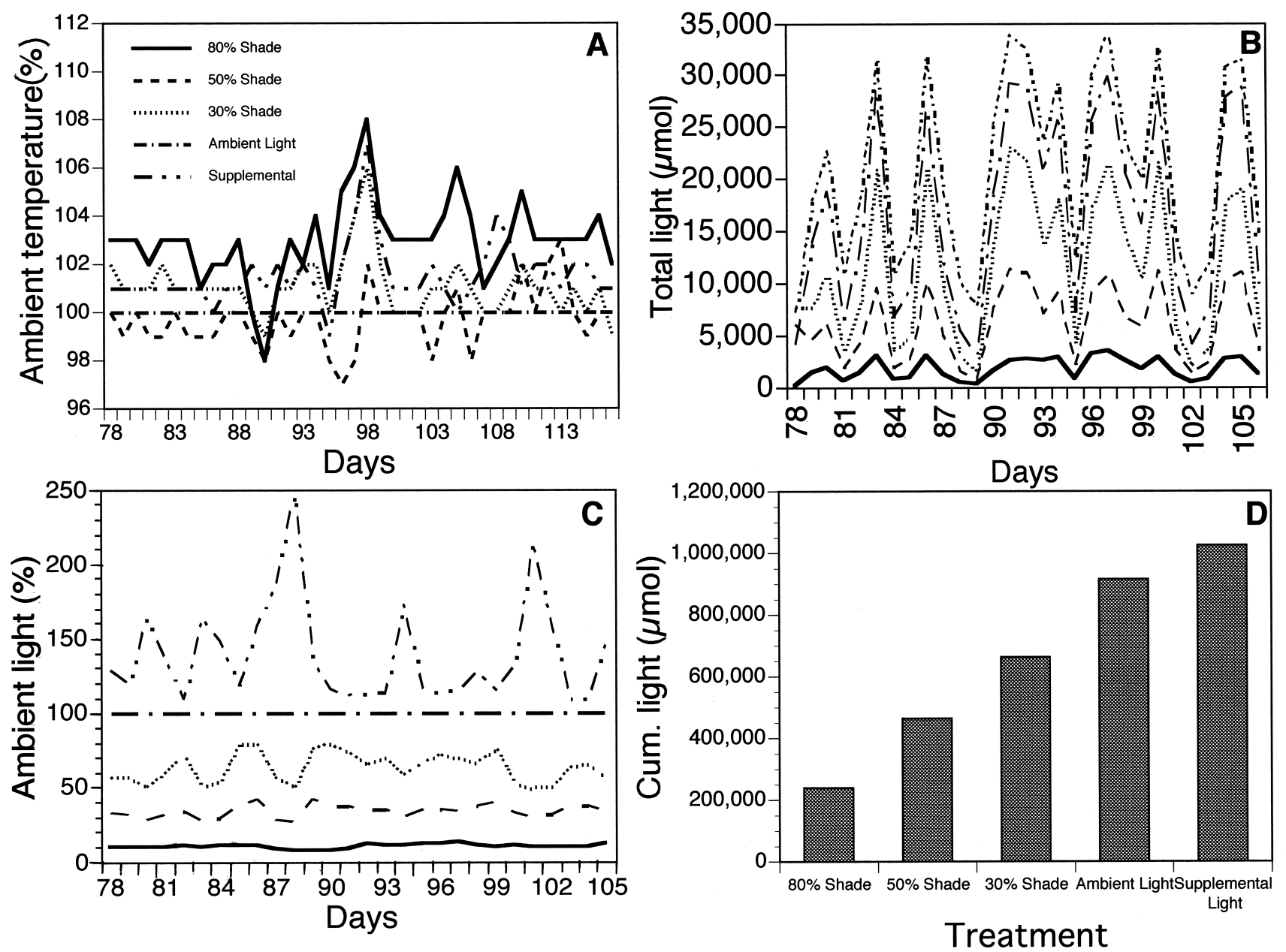

Fig. 1. Influence of five greenhouse irradiances created by adding supplemental light or shade on (A) temperature at cluster height as a percentage of ambient, (B) total light per day, (C) total light per day as a percentage of ambient, and (D) cumulative light over the 5-week treatment period.

Table 4. Influence of one or two clusters per vine and five irradiances for 5 weeks following bloom on yield, cluster size, peduncle growth, and fruit set of 'Chambourcin' grapes.

\begin{tabular}{|c|c|c|c|c|c|c|c|c|c|c|c|c|}
\hline \multirow[b]{4}{*}{ Clusters/vine } & \multirow{4}{*}{$\begin{array}{l}\text { Yield } \\
(\mathrm{g})\end{array}$} & & & \multirow{4}{*}{$\begin{array}{c}\text { Peduncle } \\
\text { growth } \\
(\mathrm{mm})^{\mathrm{z}}\end{array}$} & \multirow{2}{*}{\multicolumn{3}{|c|}{ Fruit set (\%) }} & \multirow{2}{*}{\multicolumn{2}{|c|}{ Berries }} & \multirow{4}{*}{$\begin{array}{c}\text { Berry } \\
\text { wt } \\
(\mathrm{g})\end{array}$} & \multicolumn{2}{|c|}{ Following year } \\
\hline & & \multicolumn{2}{|c|}{ Cluster } & & & & & & & & Flower & Quality $^{\mathrm{y}}$ \\
\hline & & \multirow{2}{*}{$\begin{array}{l}\text { Length } \\
(\mathrm{cm})\end{array}$} & \multirow{2}{*}{$\begin{array}{l}\text { Width } \\
(\mathrm{cm})\end{array}$} & & \multirow{2}{*}{$\begin{array}{c}\text { Shoulder } \\
\text { Good }\end{array}$} & \multicolumn{2}{|c|}{ Main cluster } & \multirow[b]{2}{*}{ Shoulder } & \multirow{2}{*}{$\begin{array}{l}\text { Main } \\
\text { cluster }\end{array}$} & & \multirow{2}{*}{$\begin{array}{c}\text { clusters/ } \\
\text { shoot }\end{array}$} & \multirow{2}{*}{$\begin{array}{c}\text { of } \\
\text { cluster }\end{array}$} \\
\hline & & & & & & Good & Shot & & & & & \\
\hline 1 & 538 & 18.0 & 15.2 & 1.04 & 36.4 & 28.4 & 8.2 & 56 & 153 & 2.03 & 1.57 & 1.9 \\
\hline 2 & 909 & 17.4 & 14.5 & 0.76 & 33.6 & 27.7 & 6.3 & 96 & 296 & 2.12 & 1.32 & 1.2 \\
\hline \multicolumn{13}{|l|}{ Light } \\
\hline Supplemental & 1135 & 19.3 & 17.8 & 0.75 & 58.8 & 48.1 & 5.2 & 134 & 406 & 2.06 & 1.65 & 1.7 \\
\hline Ambient & 1054 & 20.7 & 16.7 & 0.63 & 47.0 & 37.6 & 8.5 & 100 & 296 & 2.27 & 1.40 & 1.4 \\
\hline Shade $30 \%$ & 675 & 17.1 & 14.5 & 0.54 & 30.0 & 23.1 & 8.4 & 63 & 182 & 2.20 & 1.35 & 1.6 \\
\hline Shade $50 \%$ & 516 & 17.9 & 12.8 & 1.26 & 24.6 & 19.0 & 5.3 & 45 & 139 & 2.73 & 1.65 & 1.9 \\
\hline Shade $80 \%$ & 236 & 13.5 & 12.1 & 1.37 & 12.0 & 10.1 & 8.9 & 38 & 82 & 1.52 & 1.22 & 1.2 \\
\hline \multicolumn{13}{|l|}{ Significance } \\
\hline Cluster & $* *$ & NS & NS & $*$ & NS & NS & NS & $* *$ & $* *$ & NS & $* *$ & $* *$ \\
\hline Light & $* *$ & $* *$ & $* *$ & $* *$ & $* *$ & $* *$ & NS & $* *$ & $* *$ & $* *$ & $*$ & NS \\
\hline Cluster $\times$ light & NS & NS & NS & NS & NS & NS & NS & NS & $* *$ & $*$ & NS & $*$ \\
\hline \multicolumn{13}{|l|}{ Light } \\
\hline Linear & $* *$ & $* *$ & $* *$ & $* *$ & $* *$ & $* *$ & NS & $* *$ & $* *$ & $* *$ & $* *$ & NS \\
\hline Quadratic & NS & NS & NS & NS & NS & $*$ & NS & $* *$ & $* *$ & $* *$ & NS & $*$ \\
\hline
\end{tabular}

${ }^{\mathrm{z}}$ Change in diameter from bloom to harvest.

y'Rating scale : $1=$ sparse cluster with few flowers to $4=$ dense cluster with many flowers.

ns, ${ }^{* * * *}$ Nonsignificant or significant at $P<0.05$ or 0.01 , respectively; $\mathrm{L}=$ linear, $\mathrm{Q}=$ quadratic. 


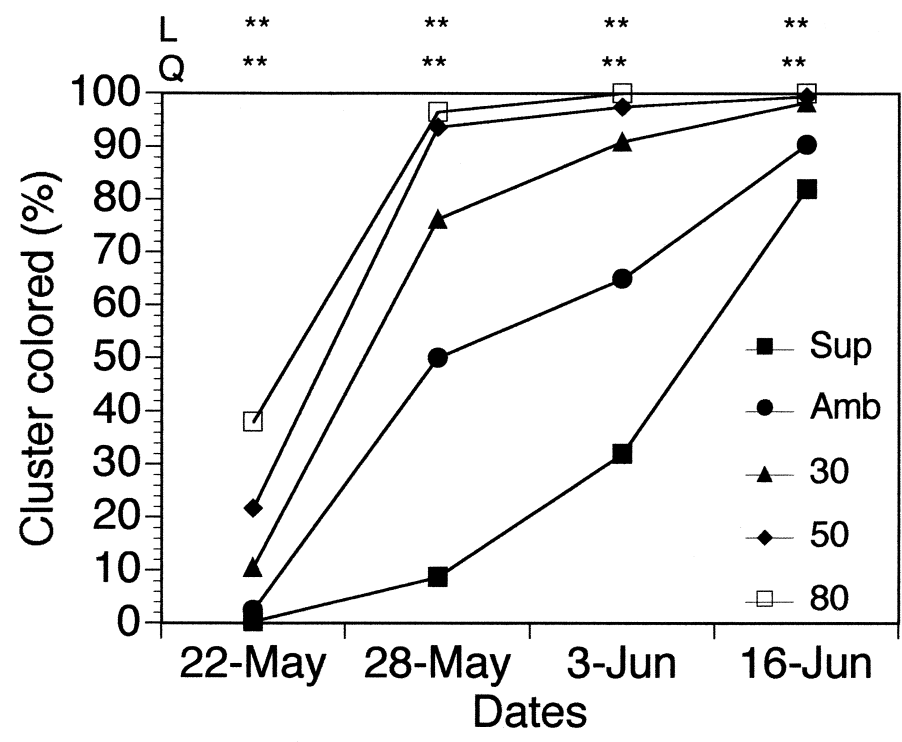

Fig. 2. Development of red color of 'Chambourcin' grape clusters exposed to irradiance regimes for ambient (Amb), ambient plus 1000W HID (Sup), 30\% shade (30), $50 \%$ shade (50), and $80 \%$ shade (80) for 5 weeks beginning at bloom. ** Significant at $P \leq 0.01$.

counts for the shoulder and main portion of the cluster was to determine the relationship in hopes of reducing the amount of counting in future studies if counts of the shoulder were sufficient. The correlation between the number of berries on the shoulder and that on the main cluster was $r=0.95$; likewise, the correlation between berry set on the shoulder and main cluster was $r=0.97$. Thus, it appears that counts of the shoulder would adequately represent the treatment effects in this study. Having two clusters per vine decreased the number of flower clusters per shoot the following year and the quality of those clusters.

Veraison began earliest on clusters with the least amount of light during the 5 weeks after bloom ( $80 \%$ and $50 \%$ shade) and these clusters reached full color by 28 May (Fig. 2). Clusters with large size and heavy set (Table 4) developed color slowly and vines growing under supplemental light with the heaviest crop never had all berries completely colored. Vines with two clusters had increased $\mathrm{pH}$ and decreased SSC compared to vines with one cluster (Table 5). Cluster number per vine had no effect on TA or berry color. Juice pH, SSC and hue angle increased with decreasing irradiance, while SI declined as irradiance decreased.

Cluster number had no effect on $\mathrm{P}_{\mathrm{n}}$ or $\mathrm{E}$ under the treatment light conditions, but both $\mathrm{P}_{\mathrm{n}}$ and $\mathrm{E}$ were lower on vines with two clusters when the vines were removed from the treatment conditions and exposed to saturating light conditions (Table 6). Both $\mathrm{P}_{\mathrm{n}}$ and $E$ increased as irradiance increased under the imposed treatments, but when vines were removed from the treatments and subjected to saturating light conditions, neither was influenced. No carryover effects of postbloom light environment were observed when $P_{n}$ and $E$ were measured under saturating light 30 and $60 \mathrm{~d}$ after vines had been returned to ambient light conditions. Vines with two clusters had reduced specific leaf weight (leaf dry weight/leaf area), and increasing irradiance increased specific leaf weight. In a leaf that expanded during the light treatments, increasing irradiance caused a decrease in total chlorophyll and an increase in chlorophyll a/b ratio. A similar trend was found in a leaf that was fully expanded at the time treatments were imposed.

Cluster weight of 'Vidal' also declined as irradiance decreased, but the difference in cluster weight between the largest cluster under supplemental light and the smallest cluster in $80 \%$ shade was 9\% less than with 'Chambourcin' (Table 7). Fruit set and berries per cluster also declined linearly with decreasing light, but the percentage reduction from the extremes was much less for 'Vidal' (38\% and 61\%) than for 'Chambourcin' (79\% and $72 \%$ ). Juice $\mathrm{pH}$ and TA of 'Vidal' declined with decreasing light. $\mathrm{P}_{\mathrm{n}}$ and $\mathrm{E}$ declined with decreasing irradiance when measured in the light environments, but there was no effect of treatment on leaf gas exchange variables under a saturating irradiance (Table 8). Specific leaf weight declined with decreasing light level and the percentage of decline from the extreme was the same for both cultivars. Total chlorophyll increased with decreasing light and the difference from the extremes was greater for 'Vidal' than for

Table 5. Influence of one or two clusters per vine and five irradiances for 5 weeks following bloom on juice composition and berry color at harvest of 'Chambourcin' grapes.

\begin{tabular}{|c|c|c|c|c|c|}
\hline \multirow[b]{3}{*}{ Clusters/vine } & \multicolumn{3}{|c|}{ Juice composition } & \multirow{2}{*}{\multicolumn{2}{|c|}{$\begin{array}{l}\text { Berry } \\
\text { color }\end{array}$}} \\
\hline & \multirow[b]{2}{*}{$\mathrm{pH}$} & \multirow[b]{2}{*}{ SSC } & \multirow{2}{*}{$\begin{array}{c}\text { TA } \\
\left(\mathrm{g} \cdot \mathrm{L}^{-1}\right)\end{array}$} & & \\
\hline & & & & Hue & SI \\
\hline 1 & 3.49 & 18.2 & 9.0 & 88.5 & 15.5 \\
\hline 2 & 3.60 & 15.3 & 8.9 & 88.1 & 15.9 \\
\hline \multicolumn{6}{|l|}{ Light } \\
\hline Supplemental & 3.13 & 12.3 & 9.8 & 86.0 & 16.7 \\
\hline Ambient & 3.27 & 13.5 & 8.3 & 88.1 & 16.1 \\
\hline Shade $30 \%$ & 3.42 & 18.2 & 8.7 & 88.8 & 15.1 \\
\hline Shade $50 \%$ & 3.60 & 19.8 & 8.2 & 89.5 & 15.5 \\
\hline Shade $80 \%$ & 3.73 & 21.0 & 8.5 & 89.5 & 15.0 \\
\hline \multicolumn{6}{|l|}{ Significance } \\
\hline Cluster (C) & $* *$ & $* *$ & NS & NS & NS \\
\hline Light (L) & $* *$ & $* *$ & $* *$ & $* *$ & $* *$ \\
\hline Cluter $\times$ light & NS & NS & NS & NS & NS \\
\hline \multicolumn{6}{|l|}{ Light } \\
\hline Linear & $* *$ & $* *$ & $*$ & $* *$ & $* *$ \\
\hline Quadratic & NS & NS & $*$ & $*$ & NS \\
\hline
\end{tabular}

ss, ${ }^{* * *}$ Nonsignificant or significant at $P<0.05$ or 0.01 , respectively; $\mathrm{L}=$ linear, $\mathrm{Q}=$ quadratic. 
Table 6. Influence of one or two clusters per vine and five irradiances for 5 weeks following bloom on net photosynthesis, transpiration, specific leaf weight, and leaf chlorophyll of 'Chambourcin' grape leaves.

\begin{tabular}{|c|c|c|c|c|c|c|c|c|c|}
\hline \multirow[b]{5}{*}{ Clusters/vine } & & & & & \multirow{5}{*}{$\begin{array}{c}\text { Specific } \\
\text { leaf wt } \\
\left(\mathrm{mg} \cdot \mathrm{cm}^{-2}\right)\end{array}$} & \multicolumn{4}{|c|}{ Chlorophyll $\left(\mu \mathrm{g} \cdot \mathrm{cm}^{-2}\right)$} \\
\hline & & & & & & \multicolumn{4}{|c|}{ Expanded leaf } \\
\hline & \multirow{2}{*}{\multicolumn{2}{|c|}{$\begin{array}{l}\text { Net photosynthesis } \\
\left(\mathrm{CO}_{2,} \mu \mathrm{mol} \cdot \mathrm{m}^{-2} \cdot \mathrm{s}^{-1}\right)\end{array}$}} & \multirow{2}{*}{\multicolumn{2}{|c|}{$\begin{array}{c}\text { Transpiration } \\
\left(\mathrm{H}_{2} \mathrm{O}, \mu \mathrm{g} \cdot \mathrm{m}^{-2} \cdot \mathrm{s}^{-1}\right)\end{array}$}} & & \multicolumn{2}{|c|}{ During treatment } & \multicolumn{2}{|c|}{ Before treatment } \\
\hline & & & & & & \multirow[b]{2}{*}{ Total } & \multirow{2}{*}{$\begin{array}{c}\mathrm{a} / \mathrm{b} \\
\text { ratio }\end{array}$} & \multirow[b]{2}{*}{ Total } & \multirow{2}{*}{$\begin{array}{l}\mathrm{a} / \mathrm{b} \\
\mathrm{ratio}\end{array}$} \\
\hline & Ambient & Saturated & Ambient & Saturated & & & & & \\
\hline$\overline{1}$ & 9.1 & 9.3 & 6.6 & 9.7 & 4.96 & 54.0 & 3.36 & 32.6 & 3.36 \\
\hline 2 & 9.1 & 8.4 & 6.4 & 8.4 & 4.77 & 53.8 & 3.38 & 33.2 & 3.13 \\
\hline \multicolumn{10}{|l|}{ Light } \\
\hline Supplemental & 12.2 & 9.2 & 7.2 & 9.2 & 6.17 & 48.3 & 3.53 & 29.8 & 3.45 \\
\hline Ambient & 10.6 & 9.2 & 7.5 & 9.5 & 5.34 & 52.1 & 3.54 & 32.1 & 3.44 \\
\hline Shade $30 \%$ & 9.4 & 9.0 & 6.4 & 9.2 & 4.91 & 54.2 & 3.26 & 34.1 & 3.26 \\
\hline Shade $50 \%$ & 7.9 & 8.7 & 5.3 & 8.6 & 4.38 & 59.3 & 3.31 & 36.1 & 3.30 \\
\hline Shade $80 \%$ & 5.3 & 7.8 & 6.2 & 8.5 & 3.52 & 55.6 & 3.10 & 32.5 & 3.22 \\
\hline \multicolumn{10}{|l|}{ Significance } \\
\hline Cluster & NS & $*$ & NS & $* *$ & $*$ & NS & NS & NS & NS \\
\hline Light & $* *$ & NS & $* *$ & NS & $* *$ & $* *$ & $* *$ & NS & NS \\
\hline \multicolumn{10}{|l|}{ Light } \\
\hline Linear & $* *$ & NS & $*$ & NS & $* *$ & $* *$ & $* *$ & $*$ & $* *$ \\
\hline Quadratic & NS & NS & NS & NS & NS & $*$ & NS & $*$ & NS \\
\hline
\end{tabular}

$\overline{\mathrm{Ns}, *, * * *}$ Nonsignificant or significant at $P<0.05$ or 0.01 , respectively; $\mathrm{L}=$ linear, $\mathrm{Q}=$ quadratic.

'Chambourcin'. The chlorophyll a/b ratio declined with decreasing irradiance in a leaf that developed during the treatments, but there was no effect in a leaf developed before imposition of the treatments.

\section{Discussion}

The present study found large differences among FrenchAmerican hybrid grape cultivars exposed to a short period of intense shade with 'DeChaunac' and 'Vidal' showing no differences in fruit set, cluster weight, berries per cluster, and shot berries (Table 2), with 'Chambourcin' being most sensitive and 'Seyval' being intermediate. Although differences existed as expected among the cultivars (Table 1), these differences would not readily explain the differences among the cultivars in their responses to the imposed short periods of shade. It is unfortunate that leaf area was not measured at the time treatments were imposed, but 'Chambourcin', which had the greatest response to the treatments, appeared to have the greatest leaf area. 'Vidal' had relatively small vines, with a shorter shoot and smaller leaves, but had nearly $50 \%$ set, which is higher than the $20 \%$ to $30 \%$ generally reported for grapes (Mullins et al., 1992). An earlier study (Hummell and Ferree, 1997) comparing low and high irradiances from $5 \mathrm{~mm}$ berry size through harvest, found 'Seyval' more sensitive to low light than 'DeChaunac' for the following responses: rachis diameter, average berry weight, $\mathrm{SSC}$ and $\mathrm{pH}$. However, 'DeChaunac' was more sensitive than 'Seyval' for the following: cluster weight, berries per cluster, yield, tartaric acid concentration, and TA. The short period of shade in the present study had no effect on rachis diameter, $\mathrm{SSC}, \mathrm{pH}$, and cluster weight of either 'DeChaunac' or 'Seyval'. Thus, it must be emphasized that 'DeChaunac', although insensitive to a short period of shade in the present study was influenced by extended intense shade for the majority of the season in the previous work. Roubelakis and Kliewer (1976) also found large differences in $V$. vinifera cultivars with 'Carignane' being most tolerant to low light $\left(\approx 112 \mu \mathrm{mol} \cdot \mathrm{m}^{-2} \cdot \mathrm{s}^{-1}\right)$ and producing higher fruit set than other cultivars. None of the $V$. vinifera cultivars set fruit at the lowest light level in their study $\left(\approx 72 \mu \mathrm{mol} \cdot \mathrm{m}^{-2} \cdot \mathrm{s}^{-1}\right)$. On a clear, sunny day the $80 \%$ shade cloth in the present study provided $\approx 155$

Table 7. Influence of five irradiances for 5 weeks following bloom on cluster weight, fruit set, berries per cluster, and juice components of 'Vidal blanc' grapes.

\begin{tabular}{|c|c|c|c|c|c|c|c|c|}
\hline \multirow[b]{3}{*}{ Light } & \multirow{3}{*}{$\begin{array}{c}\text { Cluster } \\
\text { wt } \\
\text { (g) }\end{array}$} & \multirow{2}{*}{\multicolumn{2}{|c|}{$\begin{array}{c}\text { Fruit set } \\
\qquad(\%)\end{array}$}} & \multirow{2}{*}{\multicolumn{2}{|c|}{$\begin{array}{l}\text { Berries/ } \\
\text { cluster }\end{array}$}} & \multicolumn{3}{|c|}{$\begin{array}{c}\text { Juice } \\
\text { components }\end{array}$} \\
\hline & & & & & & \multirow[b]{2}{*}{$\mathrm{pH}$} & \multirow{2}{*}{$\begin{array}{l}\text { SSC } \\
(\%)\end{array}$} & \multirow{2}{*}{$\begin{array}{c}\text { TA } \\
\left(\mathrm{g} \cdot \mathrm{L}^{-1}\right)\end{array}$} \\
\hline & & Good & Shot & Good & Shot & & & \\
\hline Supplemental & 220 & 42.9 & 6.8 & 129 & 16 & 3.32 & 21.7 & 7.7 \\
\hline Ambient & 234 & 37.3 & 3.7 & 155 & 16 & 3.33 & 22.2 & 7.8 \\
\hline Shade $30 \%$ & 134 & 31.9 & 3.1 & 99 & 10 & 3.37 & 19.5 & 7.6 \\
\hline Shade $50 \%$ & 146 & 32.4 & 4.1 & 95 & 13 & 3.40 & 22.4 & 7.3 \\
\hline Shade $80 \%$ & 67 & 26.3 & 7.0 & 50 & 15 & 3.58 & 22.0 & 6.4 \\
\hline Linear & $*$ & $*$ & NS & $* *$ & NS & $* *$ & NS & $*$ \\
\hline Quadratic & NS & NS & $*$ & NS & NS & NS & $*$ & NS \\
\hline
\end{tabular}

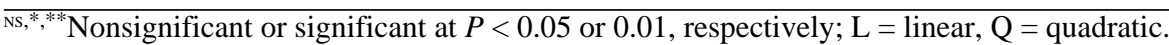


Table 8. Influence of five irradiances for 5 weeks following bloom on net photosynthesis, transpiration, specific leaf weight, and leaf chlorophyll of 'Vidal blanc' grapes.

\begin{tabular}{|c|c|c|c|c|c|c|c|c|c|c|c|}
\hline \multirow[b]{4}{*}{ Light } & \multirow{3}{*}{\multicolumn{3}{|c|}{$\begin{array}{l}\text { Net photosynthesis } \\
\left(\mathrm{CO}_{2} \mu \mathrm{mol} \cdot \mathrm{m}^{-2} \cdot \mathrm{s}^{-1}\right)\end{array}$}} & \multirow{3}{*}{\multicolumn{3}{|c|}{$\begin{array}{c}\text { Transpiration } \\
\left(\mathrm{H}_{2} \mathrm{O}, \mu \mathrm{g} \cdot \mathrm{m}^{-2} \cdot \mathrm{s}^{-1}\right)\end{array}$}} & \multirow{4}{*}{$\begin{array}{c}\text { Specific } \\
\text { leaf wt } \\
\left(\mathrm{mg} \cdot \mathrm{cm}^{-2}\right)\end{array}$} & \multicolumn{4}{|c|}{ Chlorophyll } \\
\hline & & & & & & & & \multicolumn{4}{|c|}{ Expanded leaf } \\
\hline & & & & & & & & \multicolumn{2}{|c|}{ During treatment } & \multicolumn{2}{|c|}{ Before treatmen } \\
\hline & $\begin{array}{c}P A R \\
\left(\mu \mathrm{mol} \cdot \mathrm{m}^{-2} \cdot \mathrm{s}^{-1}\right)\end{array}$ & Ambient & Saturated & $\begin{array}{c}P A R \\
\left(\mu \mathrm{mol} \cdot \mathrm{m}^{-2} \cdot \mathrm{s}^{-1}\right)\end{array}$ & Ambient & Saturated & & Total & $\begin{array}{c}\mathrm{a} / \mathrm{b} \\
\text { ratio }\end{array}$ & Total & $\begin{array}{l}\mathrm{a} / \mathrm{b} \\
\text { ratio }\end{array}$ \\
\hline Supplemental & 1471 & 8.71 & 6.64 & 1430 & 4.81 & 8.16 & 5.17 & 26.4 & 3.58 & 31.6 & 3.29 \\
\hline Ambient & 1235 & 7.32 & 5.09 & 1481 & 4.94 & 6.62 & 4.49 & 31.3 & 3.50 & 30.9 & 3.38 \\
\hline Shade $30 \%$ & 838 & 5.11 & 3.82 & 1281 & 3.58 & 4.88 & 3.81 & 37.5 & 3.29 & 39.4 & 3.21 \\
\hline Shade $50 \%$ & 461 & 5.13 & 5.58 & 1326 & 3.25 & 6.28 & 3.60 & 41.8 & 3.12 & 40.1 & 3.28 \\
\hline Shade $80 \%$ & 155 & 3.4 & 3.72 & 1286 & 2.76 & 5.79 & 2.97 & 45.9 & 2.95 & 36.1 & 3.14 \\
\hline Linear & $* *$ & $* *$ & NS & $* *$ & NS & NS & $*$ & $* *$ & $* *$ & $*$ & NS \\
\hline Quadratic & NS & NS & NS & NS & NS & NS & NS & NS & NS & NS & NS \\
\hline
\end{tabular}

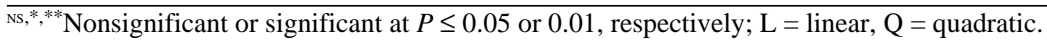

$\mu \mathrm{mol} \cdot \mathrm{m} \cdot{ }^{-2} \cdot \mathrm{s}^{-1}$. Smart $(1985,1987)$ has reported grape canopy light levels as low as $10 \mu \mathrm{mol} \cdot \mathrm{m}^{-2} \cdot \mathrm{s}^{-1}$, which shows that natural grape canopies can have lower irradiances than used in this study. Byers and Carbaugh (1991) reported that $2 \mathrm{~d}$ of artificial polypropylene shading $(92 \%)$ was nearly equivalent to $3 \mathrm{~d}$ of cloudy weather that occurs at least once in most seasons in Virginia.

A review of light levels during May and June over the last 16 years, when grapes normally bloom in Wooster, Ohio, revealed 19 periods of three or more consecutive days when irradiance was $60 \%$ to $80 \%$ below the long-term average. There were only 2 years when this type of shade event did not occur. Thus, the short shade treatments in the present study reflect the light environment grapes encounter in the field.

Fruit set of 'Chambourcin' was not reduced by shade that occurred 2 or 4 weeks after bloom, but cluster weight was reduced at both these times (Table 2). The explanation for this appears to be the increase in shot berries. Shading at or soon after bloom likely causes abscission of whole flowers, whereas, later shading does not result in abscission of flowers, but rather retention of berries that failed to develop fully. A similar pattern appears to exist for 'Seyval' except that cluster weight was not influenced. An extended period of shade also increased shot berries in a previous study on both 'Seyval' and 'DeChaunac' (Hummell and Ferree, 1997).

The leaf area required to mature a gram of fruit ranges from 7 to $15 \mathrm{~cm}^{2}$ for $V$. vinifera cultivars (Kliewer, 1970; Kliewer and Antcliff, 1970; May et al., 1969). Kaps and Cahoon (1992) found 8 to $10 \mathrm{~cm}^{2}$ of leaf area per gram of fruit was needed to maximize fruit weight and soluble solids of 'Seyval', but vegetative growth continued to increase up to $15 \mathrm{~cm}^{2} \cdot \mathrm{g}^{-1}$. In the present study leaf area for 'Chambourcin' with one and two clusters was 10.3 and 5.5 , respectively, and $7.7 \mathrm{~cm}^{2} \cdot \mathrm{g}^{-1}$ for 'Vidal'. If $15 \mathrm{~cm}^{2} \cdot \mathrm{g}^{-1}$ is more than adequate to mature fruit, the $50 \%\left(13.3 \mathrm{~cm}^{2} \cdot \mathrm{g}^{-1}\right)$ and $80 \%$ $\left(31.7 \mathrm{~cm}^{2} \cdot \mathrm{g}^{-1}\right)$ shade on the single cluster vines and the $80 \%(14.6$ $\mathrm{cm}^{2} \cdot \mathrm{g}^{-1}$ ) shade on the two cluster 'Chambourcin' vines, show that these vines had excessive leaf area mostly due to low cluster weight. The two cluster crop on 'Chambourcin' reduced shoot length by $40 \%$ at the final measurement before removal of growth above 15 leaves. Peduncle growth, specific leaf weight and SSC were also reduced on vines with two clusters (Tables 4 and 5). Flower development the following year was decreased on vines that previously carried two clusters (Table 4). These reductions clearly demonstrated that a stress was created by a crop level of two clusters per plant. This stress due to crop level did not result in an interaction for any factor measured with the range of irradiances used in this study.

Crop level also played a dominant role on juice $\mathrm{pH}$ and SSC. Normally soluble solids are higher in vines that have high canopy light values (Smart 1985, 1987). However, crop level can be the major influence on soluble solids in well exposed canopies (Reynolds, 1989; Smart, 1985). The exceedingly large clusters from the high light level vines in this study obviously decreased color development (Fig. 2) and reduced SSC. The dramatic reduction in set by $80 \%$ shade produced the opposite effect.

$P_{n}$ and E were higher for 'Chambourcin' (Table 6) than for 'Vidal' (Table 8) under all irradiances created in the experiment and also under saturated conditions. Flore and Lakso (1989) indicate there are surprisingly few consistent differences in assimilation rate between rootstocks or cultivars within a species. Williams and Smith (1991) found no difference in Pn of three grape rootstocks. However, During (1994) found that the rates of $\mathrm{P}_{\mathrm{n}}$ and stomatal conductance were influenced by rootstock genotype and plant age and the rootstock effect appears to be scionspecific. The 'Chambourcin' vines in the present study were on 3309C rootstock, while 'Vidal' vines were own-rooted. Measurements of $P_{n}$ and $E$ under saturated conditions (Table 6 and 8) and subsequent measurements 30 and $60 \mathrm{~d}$ after removal of the vines from the light regimes showed no differences. Thus, there was no long-term impairment of these physiological processes to explain the reduction in fruit set.

Generally, increasing light levels, particularly after veraison, are associated with increasing anthocyanin levels in grape berries (Gao and Cahoon, 1998; Kliewer, 1977). However, out of 40 cultivars studied by Weaver and McCune (1960), only three cultivars failed to achieve full pigmentation if excluded from light. Cluster thinning to reduce the crop has also been shown to improve pigmentation of grapes (Gao and Cahoon, 1998; Hepner and Bravdo, 1985; Reynolds, 1989). Hummell and Ferree (1998) found that increasing the crop level delayed the shift from green in a white grape cultivar. Results of the present study with 'Chambourcin' suggest that light environment early in the season has less effect on color development than the large differences in yield caused by reduced fruit set from inadequate light.

For most of the important responses (cluster weight, cluster length and width, fruit set, berries per cluster, $\mathrm{SSC}$, and $\mathrm{pH}$ ) there was a strong linear response to decreasing irradiance (Tables 4 and 7). It was not possible to identify from this study a threshold irradiance where a marked change in response occurred. The 
study comparing response of several cultivars to short periods of shade indicated that in sensitive cultivars, bloom was the most critical period for fruit set. This was earlier than the 14 to $28 \mathrm{~d}$ period following bloom identified as the most sensitive period for severe shade to reduce fruit set of apple (Byers and Carbaugh, 1991; Byers et al., 1991; Polomski et al., 1988). It appears that grape cultivars differ greatly in their sensitivity to the effect of light on fruit set as there were large differences among the French-American hybrids in our study and previous work with $V$. vinifera (Nuno, 1993; Ollat, 1993; Roubelakis and Kliewer, 1976; and Ebadi et al., 1995, 1996).

Several studies indicate that low day/night temperatures [17/ $14{ }^{\circ} \mathrm{C}$ or $12 / 9^{\circ} \mathrm{C}$ (Ebadi et al., 1996) or $15 / 10^{\circ} \mathrm{C}$ (Roubelakis and Kliewer, 1976)] consistently cause a reduction in fruit set of $V$. vinifera. In the present study temperature effects were confounded with the light environments with most treatments causing a slight increase in temperature. Although the $50 \%$ shade treatment caused a slight reduction in temperature on most days (Fig. 3A), the lowest temperature over the entire study was 17.5 ${ }^{\circ} \mathrm{C}$ and that for only $1 \mathrm{~d}$, while the high extreme was $24{ }^{\circ} \mathrm{C}$. Considering the temperatures in previous work that reduced fruit set of $V$. vinifera, temperature likely played a minor role on fruit set in the present study.

In summary, it appears that a short period of intense shade near the time of bloom can reduce fruit set and cluster weight of sensitive French American hybrid cultivars like 'Chambourcin' and 'Seyval'. 'Chambourcin' was very sensitive to reduced irradiance for the 5-week period following bloom and the following increased linearly as irradiance increased: cluster weight, fruit set, specific leaf weight, SI, and leaf chlorophyll. Although caution should be exercised extrapolating from a greenhouse study to field performance, fruit set may be reduced in years with low light conditions that occur near the time of bloom and would likely be increased when high light conditions exist.

\section{Literature Cited}

Byers, R.E. and D.H. Carbaugh. 1991. Effect of chemical thinning sprays on apple fruit set. HortTechnology (Oct./Dec.):41-48.

Byers, R.E., D.H. Carbaugh, C.N. Presley, and T.K. Wolf. 1991. The influence of low light on apple fruit abscission. J. Hort. Sci. 66:7-17.

Doud, D.S. and D.C. Ferree. 1980. Influence of altered light levels on growth and fruiting of mature 'Delicious' apple trees. J. Amer. Soc. Hort. Sci. 105:325-328.

During, H. 1994. Photosynthesis of ungrafted and grafted grapevines: Effects of rootstock genotype and plant age. Amer. J. Enol. Viticult. 45:297-299.

Ebadi, A., B.G. Coombe, and P. May. 1995. Fruit set on small 'Chardonnay' and 'Shiraz' vines grown under varying temperature regimes between bud burst and flowering. Austral. J. Grape Wine Res. 1:3-10.

Ebadi, A., P. May, and B.G. Coombe. 1996. Effect of short-term temperature and shading on fruit set, seed and berry development in model vines of $V$. vinifera cv. Chardonnay and Shiraz. Austral. J. Grape Wine Res. $2: 2-9$.

Ferree, D. 1980. Canopy development and yield efficiency of 'Golden Delicious' apple trees in four orchard management systems. J. Amer. Soc. Hort. Sci. 105:376-380.

Flore, J.A. and A.N. Lakso. 1989. Environmental and physiological regulation of photosynthesis in fruit crops. Hort. Rev. 11:111-157.

Gao, Y. and G. Cahoon. 1998. Cluster thinning effects on fruit weight, juice quality and fruit skin characteristics in 'Reliance' grapes. Fruit Crops 1998: Ohio Agr. Res. Dev. Ctr. Res. Circ. 299:87-93.

Hepner, Y. and B. Bravdo. 1985. Effect of crop level and drip irrigation scheduling on the potassium status of 'Cabernet Sauvignon' and 'Carignane' vine and its influence on must and wine composition and quality. Amer. J. Enol. Viticult. 36:140-147.

Hummell, A.K. and D.C. Ferree. 1997. Response of two french hybrid wine-grape cultivars to low light environments. Fruit Var. J. 51:101-111.

Hummell, A.K. and D.C. Ferree. 1998. Interaction of crop level and fruit cluster exposure on 'Seyval Blanc' fruit composition. J. Amer. Soc. Hort. Sci. 123:755-761.

Kaps, M.L. and G.A. Cahoon. 1992. Growth and fruiting of containergrown 'Seyval Blanc' grapevines modified by changes in crop level, leaf number and position, and light exposure. Amer. J. Enol. Viticult. 43:191199.

Kliewer, W.M. 1970. Effect of time of severity of defoliation on growth and composition of 'Thompson Seedless' grapes. Amer. J. Enol. Viticult. 21:37-47.

Kliewer, W.M. 1977. Influence of temperature, solar radiation and nitrogen on coloration and composition of 'Emperor' grapes. Amer. J. Enol. Viticult. 28:96-103.

Kliewer, W.M. and A.J. Antcliff. 1970 Influence of defoliation, leaf darkening and cluster shading on the growth and composition of 'Sultana' grapes. Amer. J. Enol. Viticult. 21:26-36.

May, P., N.J. Shaulis, and A.J. Antcliff. 1969. The effect of controlled defoliation in the Sultana vines. Amer. J. Enol. Viticult. 20:237-250.

Moran, R. 1982. Formulae for determination of chlorophyllous pigments extracted with N,N-dimethylformamide. Plant Physiol. 69:1376-1381.

Mullins, M.G., A. Bouquet, and L.E. Williams. 1992. Biology of the grapevine. Cambridge Univ. Press, Cambridge, United Kingdom.

Nuno, M. 1993. Influence de la reduction de la PAR sur la nouaison chez Vitis vinifera. Proc. IV Intl. Symp. Grapevine Physiol. (Fondazione Giovanni Dalmasso:Torino). p. 559-564.

Ollat, N. 1993. Nouaison chez Vitis vinifera L. cv. 'Merlot Noir': Role de intensite lumineuse et de la photoynthese a la floraison. Proc. IV Intl. Symp. Grapevine Physiol.(Foundazione Giovanni Dalmasso: Torino).p. 113-116.

Polomski, R.F., J.A. Barden, R.E. Byers, and D.D. Wolf. 1988. Apple fruit nonstructural carbohydrates and abscission as influenced by shade and terbacil. J. Amer. Soc. Hort. Sci. 113:506-511.

Reynolds, A.G. 1989. Impact of pruning, cluster thinning, and shoot removal on growth, yield and fruit composition of low-vigor 'DeChaunac' vines. Can. J. Plant Sci. 69:269-275.

Roubelakis, K.A. and W.M. Kliewer. 1976. Influence of light intensity and growth regulators on fruit set and ovule fertilization in grape cultivars under low temperature conditions. Amer. J. Enol. Viticult. 27:163-167.

Smart, R.E. 1985. Principles of grapevine canopy microclimate manipulation with implications for yield and quality: A review. Amer. J. Enol. Viticult. 36:230-239.

Smart, R.E. 1987. Influence of light on composition and quality of grapes. Acta Hort. 206:37-45.

Warrington, I.J., C.J. Stanley, D.S. Tustin, P.M. Hirst, and W.M. Cashmore. 1996. Light transmission, yield distribution, and fruit quality in six tree canopy forms of 'Granny Smith' apple. J. Tree Fruit Prod. 1:27-54.

Weaver, R.J. and S.B. McCune. 1960. Influence of light on color development of Vitis vinifera grapevines. Amer. J. Enol. Viticult. 11:179-184.

Williams, L.E. and R.J. Smith. 1991. The effect of rootstock on the partitioning of dry weight, nitrogen and potassium, and root distribution of Cabernet Sauvignon grapevines. Amer. J. Enol. Viticult. 42:118-122. 